\title{
GH/STAT5 signaling during the growth period in livers of mice overexpressing GH
}

\author{
Carolina S Martinez, Verónica G Piazza, María E Díaz, Ravneet K Boparai', Oge Arum', \\ María C Ramírez², Lorena González, Damasia Becú-Villalobos², Andrzej Bartke', \\ Daniel Turyn, Johanna G Miquet and Ana I Sotelo
}

Facultad de Farmacia y Bioquímica, Instituto de Química y Fisicoquímica Biológicas (UBA-CONICET), Universidad de Buenos Aires, Junín 956, 1113 Buenos Aires, Argentina

${ }^{1}$ Department of Geriatrics (A.B.), School of Medicine, Southern Illinois University, Springfield, Illinois, USA

${ }^{2}$ Instituto de Biología y Medicina Experimental (CONICET), Vuelta de Obligado 2490, Buenos Aires, Argentina

\begin{abstract}
GH/STAT5 signaling is desensitized in the liver in adult transgenic mice overexpressing GH; however, these animals present greater body size. To assess whether the STAT5 pathway is active during the growth period in the liver in these animals, and how signaling modulators participate in this process, growing transgenic mice and normal siblings were evaluated. STAT5 does not respond to an acute GH-stimulus, but displays higher basal phosphorylation in the livers of growing $\mathrm{GH}$-overexpressing mice. $\mathrm{GH}$ receptor and the positive modulators glucocorticoid receptor and HNF1 display greater abundance in transgenic animals, supporting the activity of STAT5. The negative modulators cytokine-induced suppressor and PTP1B are increased in GH-overexpressing mice. The suppressors SOCS2 and SOCS3 exhibit higher mRNA levels in transgenic mice but lower protein content, indicating that they are being actively degraded. Therefore, STAT5 signaling is increased in the liver in GH-transgenic mice during the growth period, with a balance between positive and negative effectors resulting in accelerated but controlled growth.
\end{abstract}

Correspondence should be addressed to A I Sotelo

Email

aisotelo@qb.ffyb.uba.ar
Journal of Molecular

Endocrinology

(2015) 54, 171-184

\section{Introduction}

Growth hormone $(\mathrm{GH})$ is involved in the promotion of skeletal growth and in a variety of metabolic functions; its actions are accomplished both directly and indirectly by the induction of insulin-like growth factor 1 (IGF1). Liver is a primary target organ for $\mathrm{GH}$ and the major site of production of circulating IGF1, the principal mediator of the somatotropic function. Binding of $\mathrm{GH}$ to a $\mathrm{GH}$ receptor (GHR) dimer leads to cross-activation of the receptor-associated tyrosine-kinase JAK2, which phosphorylates GHR on multiple intracellular tyrosine residues (Brooks \& Waters 2010, Sedek et al. 2014). These residues
Key Words
- GH signaling
- STAT5
- GH-overexpressing mice
- growth

- liver 
the cytosolic SH2-containing protein-tyrosine phosphatases (SHP) 1 and 2, interact with GHR, JAK2 and nuclear tyrosine-phosphorylated STAT5b in a GH-dependent manner (Flores-Morales et al. 2006, Lanning \& Carter-Su 2006, Pilecka et al. 2007). In addition, GH induces the expression of suppressors of cytokine signaling (SOCS)/ cytokine-induced suppressor (CIS) proteins, CIS, SOCS1, SOCS2, and SOCS3 via the STAT5 pathway, albeit with different kinetics (Adams et al. 1998, Tollet-Egnell et al. 1999). SOCS1 and 3 inhibit JAK2 kinase activity, while CIS and SOCS2 bind to phosphotyrosine residues on the carboxy-terminus of GHR, thus interfering with recruitment of signaling mediators. Moreover, these suppressors drive signaling complexes to proteasome degradation (Kile et al. 2002, Linossi \& Nicholson 2012). In the liver, SOCS2 expression is also induced by the fasting-induced hormone, fibroblast growth factor 21 (FGF21), resulting in the inhibition of STAT5 (Inagaki et al. 2008). The influence of FGF21 on body growth is evident in transgenic mice overexpressing this factor, which exhibit reduced growth, whereas targeted-disruption of FGF21 blunts foodrestriction impairment of growth (Inagaki et al. 2008, Kubicky et al. 2012). Another protein involved in the regulation of STAT5 activity is BCL6, a strong transcriptional repressor that binds to DNA motifs distinct, but overlapping with those of STAT5, thus preventing its action. In liver, BCL6 binds preferentially to female-specific GH-regulated genes, precluding their transcription (Zhang et al. 2012).

Several transcription factors modulate STAT5 binding to DNA, including the glucocorticoid receptor (GR) and hepatocyte nuclear factor $1 \alpha$ (HNF1 $\alpha)$. Liver-specific inactivation of these positive modulators is associated with reduced somatic growth in mice (Tronche et al. 2004, Engblom et al. 2007, Lin et al. 2008). GR is a STAT5 coactivator in the liver (Tronche et al. 2004, Engblom et al. 2007), whereas HNF1a regulates GR expression to control postnatal body growth, indirectly modulating STAT5 (Lin et al. 2008).

Rodents present two phases of rapid growth. The first is independent of GH and occurs immediately after birth. The second is GH-dependent and begins soon after the 2nd week of life (Liu \& LeRoith 1999, Lupu et al. 2001, Tang et al. 2005), denoting the transition of the autocrine/paracrine control of growth to central regulation (Hyatt et al. 2004). In accordance, transgenic mice overexpressing GH exhibit accelerated growth from the third week of age, in spite of having high circulating GH levels since birth (Mathews et al. 1988, McGrane et al. 1990). As a result, they achieve greater adult body size than control mice. At adulthood, these animals present GH-induced STAT5-signaling desensitization in the liver, as it does not become phosphorylated upon an acute GH-stimulus. Moreover, basal levels of hepatic STAT5 phosphorylation in adult transgenic mice are similar to those of normal animals (Gonzalez et al. 2002, Miquet et al. 2004, Sotelo et al. 2008). Therefore, the aim of this work is to study whether this pathway is activated differentially at earlier ages, i.e., during the GH-dependent phase of growth. For this purpose, three ages were selected, one before and one after the growth burst (2- and 4-weekold animals respectively) and young adults (9-week-old control). The current work presents an in vivo study of STAT5-mediated GH-signaling in the liver in growing GH-overexpressing mice, since this pathway is directly related to IGF1 induction and longitudinal body growth. The results will contribute to understanding how the organism adapts to an excess of a hormone.

\section{Materials and methods}

\section{Animals}

Transgenic Pepck-bGh mice containing the $b G h$ gene fused to the control sequences of the rat phosphoenolpyruvate carboxykinase (Pepck) gene were derived from animals kindly provided by Dr Thomas E Wagner and Jeung S Yun (Ohio University, Athens, OH, USA). Hemizygous transgenic mice were produced by mating transgenic males with normal $\mathrm{C} 57 \mathrm{BL} / 6 \times \mathrm{C} 3 \mathrm{H}$ F1 hybrid females purchased from the Jackson Laboratory (Bar Harbor, ME, USA). Normal siblings of transgenic mice were used as controls. The mice were housed three to five per cage in a room with controlled light $\left(12 \mathrm{~h} \mathrm{light/day)}\right.$ and temperature $\left(22 \pm 2{ }^{\circ} \mathrm{C}\right)$. The animals had free access to food (Rodent Laboratory Chow 5001; not autoclaved; $23.4 \%$ protein, $4.5 \%$ fat, $5.8 \%$ crude fiber; LabDiet, PMI Feeds, Inc., St Louis, MO, USA) and tap water.

Three cohorts of animals were used. The first one was used to determine body growth at different age points. The second was used for GH-stimulation studies, while the third was used to determine the content of GH-signaling mediators as well as tibial length. In these last two cohorts, animals were 14, 28, and 63 days of age (referred to as 2, 4, and 9 weeks old). For GH-stimulation studies, female mice received $5 \mu \mathrm{g}$ ovine $\mathrm{GH}(\mathrm{oGH}) / \mathrm{g}$ of body weight (oGH was obtained through the National Hormone and Pituitary Program, NIDDK, NIH, USA) or saline solution by i.p. administration $7.5 \mathrm{~min}$ before necropsy. The animals were killed by cervical dislocation under isofluorane anesthesia, and livers were removed and stored at $-80^{\circ} \mathrm{C}$ until use.

The appropriateness of the experimental procedure, the required number of animals used, and the method of

Published by Bioscientifica Ltd. 
acquisition were in compliance with federal and local laws and institutional regulations. The experiments were approved by the SIU Laboratory Animal Care Committee.

\section{Liver solubilization and immunoblotting}

Liver solubilization, CIS immunoprecipitation, and preparation of samples for immunoblotting (IB) have been described previously (Martinez et al. 2013). For IB, each lane was loaded with $40 \mu \mathrm{g}$ of protein from whole tissue solubilizates. After blotting and blocking of PVDF membranes, they were incubated overnight at $4{ }^{\circ} \mathrm{C}$ with the following antibodies: anti-BCL6 1:1000 ( $\alpha$ BCL6; C-19, no. 368 ), anti-CIS 1:200 ( $\alpha$ CIS; N-19, no. 1529), anti-FGF21 1:1000 ( $\alpha$ FGF21; V-16, no. 16842), anti-GR 1:300 ( $\alpha \mathrm{GR}$; M-20, no. 1004), anti-HNF1 1:300 ( $\alpha$ HNF1; H-205, no. 8986), anti-MUP 1:2000 ( $\alpha$ MUP; FL-180, no. 66976), anti-SOCS2 1:600 ( $\alpha$ SOCS2; H-74, no. 9022), anti-SOCS3 1:300 (aSOCS3; H-103, no. 9023), anti-STAT5 1:10 000 (aSTAT5; C-17, no. 835) purchased from Santa Cruz Biotechnology Laboratories; anti-SHP1 1:1000 ( $\alpha$ PTP1C/SHP1, no. 610126), anti-SHP2 1:1000 ( $\alpha$ PTP1D/SHP2, no. 610622) obtained from BD Transduction Laboratories (Franklin Lakes, NJ, USA); antiphospho-STAT5a/b (Y694/Y699) 1:1000 (apSTAT5a/b, no. 05-495), anti-PTP1B 1:2500 ( $\alpha$ PTP1B, no. 07-088) purchased from Millipore Corporation (Billerica, MA, USA); or antibody anti-GHR anti serum $(\alpha \mathrm{GHR}) 1: 1000$, generously provided by Dr S J Frank (Zhang et al. 2001). Immunoreactive proteins were revealed by ECL-Plus (Amersham, GE Healthcare LifeSciences, Pittsburgh, PA, USA) using hyperfilm ECL (GE Healthcare LifeSciences), and band intensities were quantified using Gel-Pro Analyzer Software (Media Cybernetics, Silver Spring, MD, USA). Antibody dilutions were selected on the basis of on previous reports, or according to recommendations of the providers; in each case, the bands to be quantified fell within the linear range of the method.

IB experiments were designed to compare three variables in parallel: age, genotype and stimuli or age, genotype and sex. Each experimental set contained different individuals; thus, $n$, the number of individuals assayed per group also represents the number of experiments. The average of values obtained for 9-week-old male mice was used as reference (100\% value). The results are presented as mean \pm s.E.M. of the number of samples indicated.

\section{Protein loading control}

Protein loading control could not be performed by IB detection of standard proteins in the liver for this GH-overexpressing mouse model. Actin exhibited age- and genotype-dependent variation in hepatic protein abundance, whereas tubulin content did not show uniformity between genotypes (Supplementary Figure 1A, see section on supplementary data given at the end of this article) (Martinez et al. 2013, Miquet et al. 2013). Therefore, the following determinations were routinely performed. Before IB, homogeneity of sample preparation was assessed by SDS-PAGE followed by Coomassie blue staining (CBS). During IB, Ponceau staining was used to evaluate the goodness of electrotransference (Torre et al. 2011). After IB experiments, protein loading control was performed by CBS of the PVDF membranes (Welinder \& Ekblad 2011).

\section{Real-time reverse transcriptase PCR}

Total hepatic RNA was extracted using the phenol/chloroform method. cDNA was obtained using the iScript cDNA Synthesis kit (Bio-Rad), and the relative expression of the genes was analyzed by quantitative RT-PCR (qRT-PCR) as described previously (Ramirez et al. 2010). Table 1 shows the sequences of the primer sets used, obtained from Invitrogen.

This method was also used for genotyping transgenic mice, because they cannot be distinguished from their normal siblings by size at 2 weeks of age. The sequences used to determine the expression of the transgene are described in Table 1.

\section{Statistical analysis}

Statistical analysis was performed using the GraphPad Prism Statistical Program by GraphPad Software, Inc. (San Diego, CA, USA). Data were first analyzed by one-way ANOVA followed by Bonferroni's test to evaluate stimuli or sex differences. As no significant differences were found for protein or mRNA content between sexes for every age and genotype analyzed, results were presented as separate bar charts for each sex. Subsequently, data were analyzed by two-way ANOVA and Bonferroni's post test to assess differences by age and genotype. Data were considered to be statistically significant if $P<0.05$.

\section{Results}

\section{Body growth}

Body weight was determined and the expected two phases of rapid growth were observed, separated by a brief pause between days 14 and 16 . Male mice exhibited higher body weight than females. In normal mice, this difference was detected beginning at the fourth week of age; while,

Published by Bioscientifica Ltd 
Table 1 Primer sequences used for gene expression assays

\section{Gene}

$b G H$

Cis

Cyclophilin A

Ghr

$\lg f 1$

Socs2

Socs 3

Primer sequence $\left(5^{\prime} \rightarrow 3^{\prime}\right)$

Forward: GGGCAGATCCTCAAGCAGAC

Reverse: GAAGCAGGAGAGCAGACCG

Forward: TGCATAGCCAAGACGTTCTC

Reverse: GTGGGTGCTGTCTCGAACTA

Forward: GCGTCTCCTTCGAGCTGTT

Reverse: AAGTCACCACCCTGGCAC

Forward: CCAACTCGCCTCTACACC

Reverse: GGGAAAGGACTACACCACCTG

Forward: CTGAGCTGGTGGATGCTCTT

Reverse: CACTCATCCACAATGCCTGT

Forward: TGTGAGTCCCAACCTAGTGC

Reverse: GTAGAAGGGAGGCAGCTGTT

Forward: CTAGGTGAGGAGTGGTGGCT

Reverse: CTGCGAGGTTTCATTAGCTG

\section{GenBank accession number}

NM_180996.1

NM_009895.3

NM_008907.1

NM_010284.2

NM 010512.4

NM_007706.4

NM_007707.3 in transgenic animals, the difference between sexes was less pronounced. Body weights of transgenic mice were significantly different from those of non-transgenic siblings starting at day 19 (Fig. 1A). When growth rate was assessed, more noticeable differences were observed between 2 and 3 weeks of age (Fig. 1A inserts).
In order to evaluate $\mathrm{GH}$ signaling in liver during different growth periods, representative ages were chosen: 2 weeks ( $2 w)$, when animals of both genotypes still exhibit the same body weight; 4 weeks $(4 \mathrm{w})$, when transgenic mice display greater body size than normal siblings; and 9 weeks (9w; young adults) which were considered as the reference.

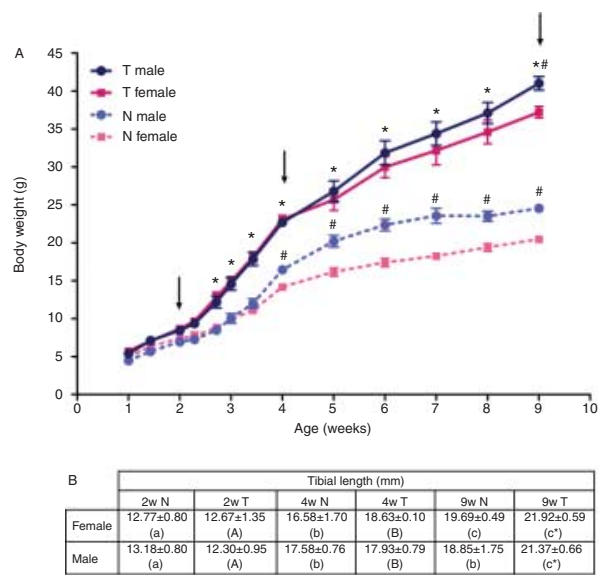

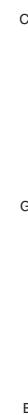

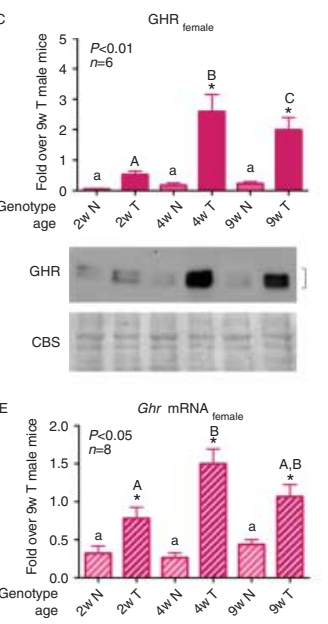

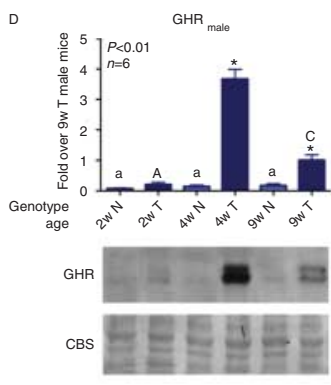

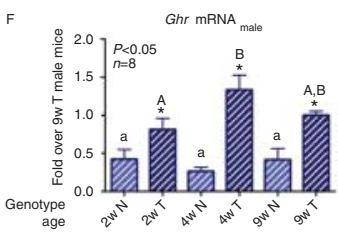

\section{Figure 1}

Body growth and GHR hepatic expression in growing GH-transgenic mice and normal littermates. (A) Body weight of $\mathrm{GH}$-overexpressing mice and normal littermates; inserts: body growth rate in female mice (i) and male mice (ii). (B) Tibial length of $\mathrm{GH}$-overexpressing mice and normal littermates. (C) GHR hepatic protein content in female mice. (D) GHR hepatic protein content in male mice. (E) Ghr mRNA hepatic expression in female mice. (F) Ghr mRNA hepatic expression in male mice. Body weight and tibial length were assessed for transgenic $(\mathrm{T})$ and normal $(\mathrm{N})$ female and male mice. Body growth rate was estimated as a percentage of body weight increment every 2 days. Data are the mean \pm s.E.M. of 10 (A) or 7 (B) samples per group, each one representing a different animal. Asterisks indicate significant differences between GH-overexpressing animals and their corresponding non-transgenic age-control, \# signs indicate significant differences between females and males of the same genotype. Arrows indicate selected working ages. Different letters denote significant differences with respect to age; lower case letters correspond to normal mice, and upper case letters to transgenic animals. To determine protein abundance, equal amounts of solubilized liver protein were assessed by immunoblotting. Coomassie blue staining (CBS) of PVDF membranes is shown. Bands were quantified by scanning densitometry. To determine gene expression, mRNA was assessed by qRT-PCR on total RNA extracts. Values were expressed as the fold increase relative to 9-week-old transgenic male mice. Data are the mean \pm s.E.M. of the indicated $n$ number of samples per group, each one representing a different animal. Different letters denote significant differences with respect to age; lower case letters correspond to normal mice and upper case letters to transgenic animals. Asterisks indicate significant difference between $\mathrm{GH}$-overexpressing animals and their corresponding non-transgenic age controls. Square brackets indicate the quantified bands. A full colour version of this figure is available at $\mathrm{http}: / / \mathrm{dx}$.doi.org/10.1530/JME-14-0262.

Published by Bioscientifica Ltd 
The selected ages are indicated by arrows in Fig. 1A. For the selected ages, tibial length was determined. The extension of the tibias increased with age both for normal and transgenic mice, but the increase was larger for GH-overexpressing animals. When tibial length was assessed by genotype, greater values were obtained for 9-week-old transgenic mice compared with controls (Fig. 1B).

\section{GHR gene expression and protein abundance}

GH binding to its receptor is the first step in $\mathrm{GH}$ signaling events. It is already established that GH induces GHR expression in liver and, accordingly, it is augmented in GH-transgenic adult animals (Miquet et al. 2004, Gonzalez et al. 2007). GHR levels have also been reported to increase with age (Maes et al. 1983, Mathews et al. 1989, Martinez et al. 2013). Moreover, it has been proposed that the magnitude of $\mathrm{GH}$ responsiveness correlates with GHR expression (Jiang et al. 2007). Therefore, it was of interest to determine its level in growing GH-overexpressing mice.

Transgenic animals presented significantly higher GHR protein abundance than normal siblings after the fourth week of age (Fig. 1C and D). For GH-overexpressing mice, values did not exhibit a gradual increase with age, but presented a maximum at 4 weeks in both sexes (Fig. 1C and $\mathrm{D}$ ). To detect whether there was any age difference in normal animals, samples had to be assessed separately, because the high GHR content in transgenic mice concealed the results. Non-transgenic littermates exhibited an age-dependent profile similar to that in GH-overexpressing animals, although the rise at 4 weeks was not as pronounced (Supplementary Figure 1A and B). Ghr mRNA expression was higher for transgenic animals at every age studied, indicating that the high protein content these mice exhibit correlates with elevated receptor gene expression in these animals (Fig. 1E and F).

\section{STAT5 activation}

STAT5 phosphorylation upon an exogenous stimulus To study GH sensitivity during the growth period, animals received a GH stimulus or saline for $7.5 \mathrm{~min}$, after which livers were collected and solubilized. Tyrosine-phosphorylation of STAT5 proteins was determined by IB with a specific antibody against the activating residue in STAT5 $a$ and b (pSTAT5). Assays were restricted to female mice to assess age and genotype simultaneously. Normal mice responded at every age studied, exhibiting maximal STAT5 phosphorylation levels at 2 weeks of age, and declining thereafter (Fig. 2A). On the other hand, transgenic mice did not respond to the stimulus at any age. As we have already assessed GH response to an exogenous stimulus in nontransgenic growing mice and found no sex differences at any age (Martinez et al. 2013), and taking in account that GH secretion is not sexually dimorphic in transgenic mice (described in the subsection 'STAT5 modulators abundance'), we would expect GH desensitization at every age in GH-transgenic male mice as well. For this reason, and due to the large number of animals required, we preferred not to carry out the experiment on male mice.

Endogenous STAT5 activation In normal mice, basal STAT5 phosphorylation levels displayed an increasing trend with age. GH-transgenic mice exhibited a different age-dependent pattern, presenting similar pSTAT5 levels for 2- and 9-week-old animals and a twofold increase at 4 weeks. When genotype differences were analyzed, GH-overexpressing growing mice achieved higher basal phosphorylation levels than control siblings (Fig. 2B and C). At 9 weeks of age, pSTAT5 did not exhibit difference with respect to genotype for female mice, while transgenic males presented lower levels than their controls. This can be attributed to similar pSTAT5 levels observed in transgenic animals of both sexes, whereas normal male mice exhibited higher levels than females, in accordance with recent observations (Miquet et al. 2013).

There is a slight discrepancy between basal STAT5 phosphorylation levels in Fig. $2 \mathrm{~A}$ and $\mathrm{B}$, this may be due to the masking of the non-stimulated signal in Fig. $2 \mathrm{~A}$, because the intensity of the endogenous signal is much weaker than that of the stimulated one.

\section{STAT5 protein content and phosphorylation/} protein content relation When $S T A T 5 \mathrm{a} / \mathrm{b}$ protein content was assayed, 2-week-old mice exhibited the highest values, with greater levels in normal animals, whereas 4- and 9-week-old mice displayed similar abundances in the two genotypes (Fig. 2E and F).

GH-induced STAT5 phosphorylation values were related to STAT5 protein abundance. STAT5 protein content was determined for non-stimulated mice only (results not shown), because phosphorylated STAT5 migrates differentially in electrophoresis, yielding an unexpected increase in IB intensity that may distort the results (Thangavel \& Shapiro 2007, Martinez et al. 2013). For saline-treated mice and GH-stimulated transgenic animals, transformed values closely resembled the original

Published by Bioscientifica Ltd 
A
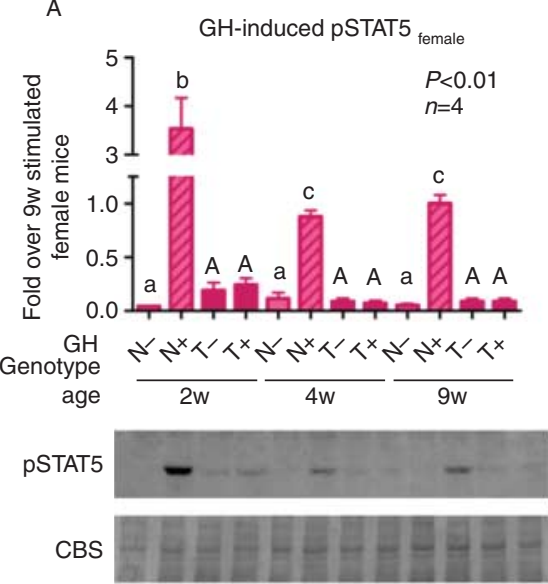

D

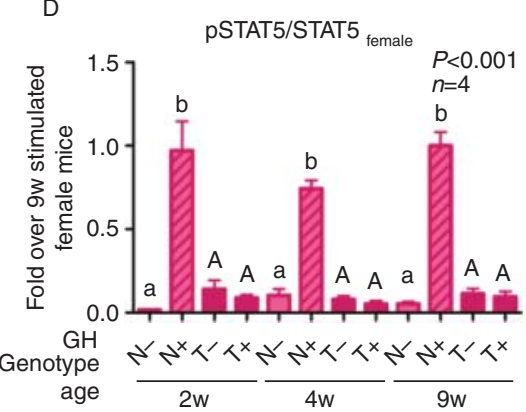

B

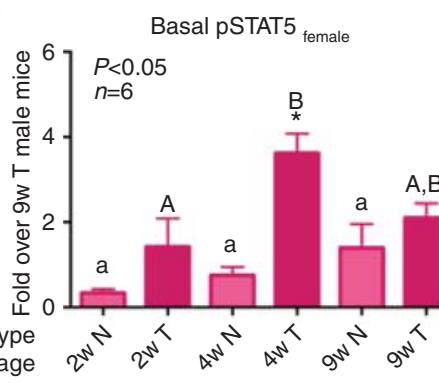

pSTAT5
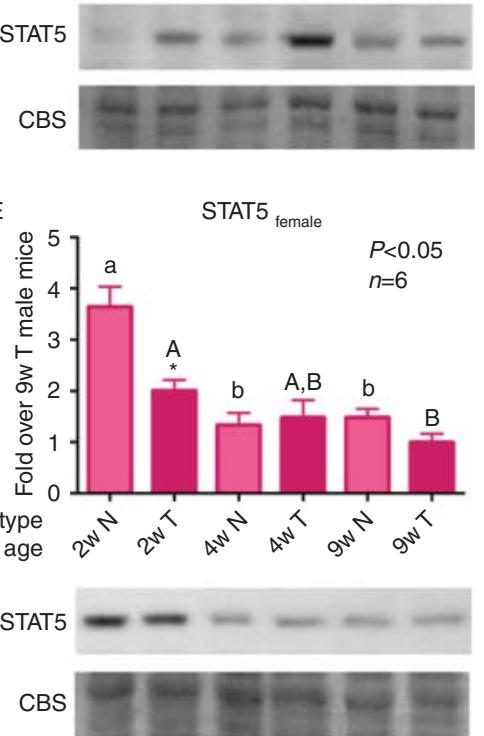

Genotyp
C

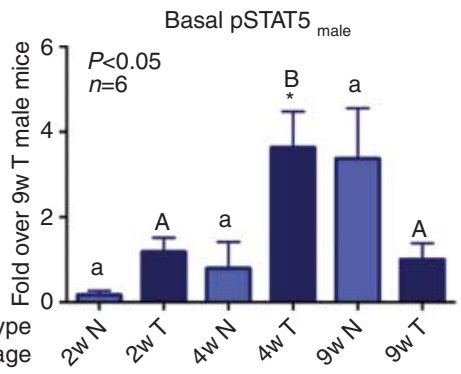

pSTAT5

CBS

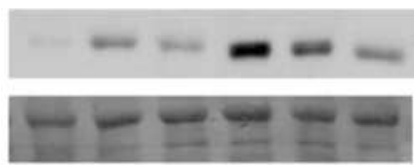

$\mathrm{F}$

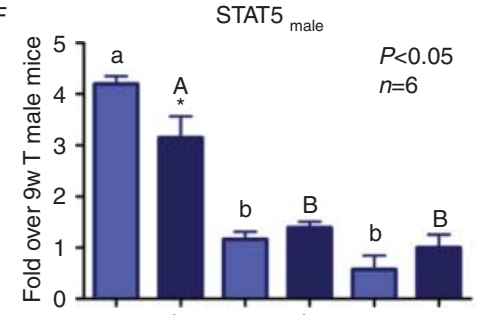
age
age

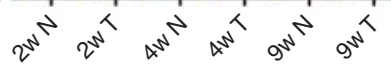

STAT5

CBS
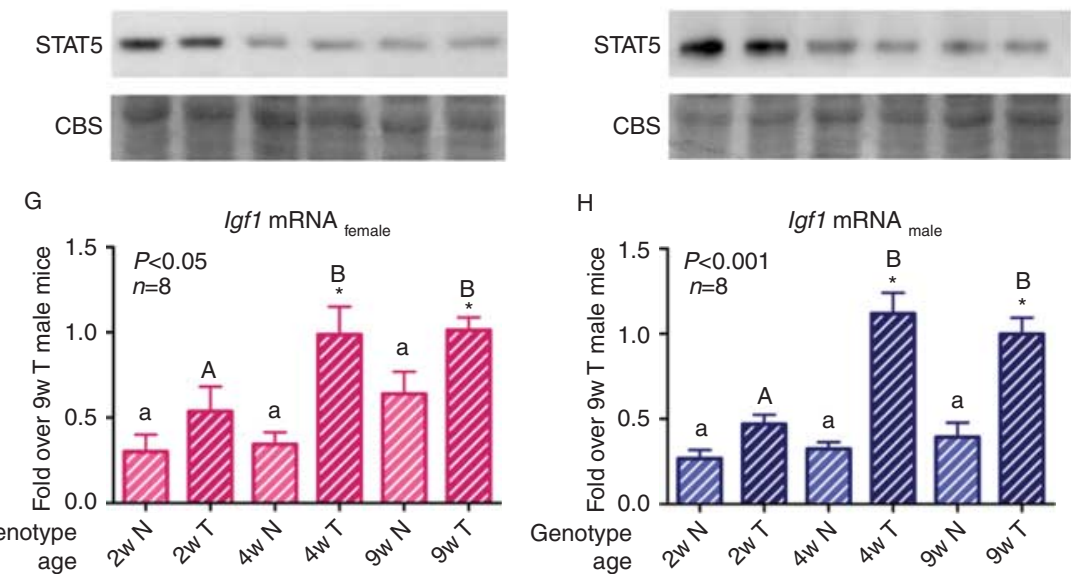

$\mathrm{H}$

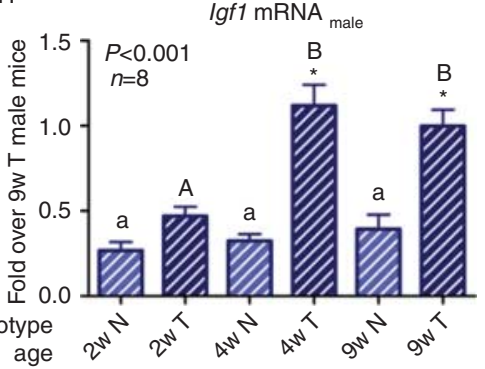

\section{Figure 2}

STAT5 signaling in the livers of growing $\mathrm{GH}$-overexpressing mice and normal littermates. (A) GH-induced STAT5-tyrosine phosphorylation in female mice. (B) Basal STAT5-tyrosine phosphorylation in female mice. (C) Basal STAT5tyrosine phosphorylation in male mice. (D) Tyrosine phosphorylation/ protein content relation for GH-induced STAT5 phosphorylation. (E) STAT5 protein abundance in female mice. (F) STAT5 protein abundance in male mice. (G) Igf1 mRNA hepatic expression in female mice. (H) Igf1 mRNA hepatic expression in male mice. Equal amounts of solubilized tissue were analyzed by immunoblotting; Coomassie blue staining (CBS) of PVDF membranes is shown. mRNA was assessed by qRT-PCR from total RNA

ones, whereas for GH-stimulated normal mice, similar results were obtained at every age studied, indicating that the pronounced GH-induced activation in 2-week-old mice is due to higher protein content at that age (Fig. 2D). extracts. Results were expressed as the fold increase over the mean value measured for $\mathrm{GH}$-stimulated 9-week-old normal female mice ( $A$ and $D$ ) or as the fold increase over 9-week-old transgenic male mice (B, C, E, F, G and H). Data are the mean \pm s.E.M. of the indicated $n$ number of samples per group, each one representing a different animal. Different letters denote significant differences with respect to age; lower case letters correspond to normal mice and upper case letters to transgenic animals. Asterisks indicate significant differences between $\mathrm{GH}$-overexpressing animals and their corresponding non-transgenic age controls. A full colour version of this figure is available at $h t t p: / / d x . d o i . o r g / 10.1530 / J M E-14-0262$.

IGF1: downstream endogenous STAT5 activation To further address this pathway, the hepatic expression of IGF1, a STAT5-mediated GH-induced gene and the principal mediator of the action of GH on somatic

Published by Bioscientifica Ltd. 
growth, was evaluated. Transgenic mice exhibited increased hepatic Igf 1 gene expression at every age studied compared with normal controls (Fig. 2G and H). Consistent with STAT5 basal phosphorylation levels, during the growth period there was an age-dependent increase in Igf1 transcription levels in transgenic animals. However, 4- and 9-week-old GH-overexpressing mice exhibited similar transcript levels, despite the different STAT5 phosphorylation levels they present. Furthermore, in adult mice, Igf 1 transcript expression does not seem to correlate with STAT5 phosphorylation status.

\section{Phosphatase protein content}

GH signaling is limited by dephosphorylation of activated mediators by specific phosphatases. Hepatic content of these enzymes was assayed, and no significant age, sex, or genotype differences were found for SHP1 and SHP2 proteins (Fig. 3A, B, C and D). On the other hand, transgenic mice presented higher PTP1B levels compared with normal siblings at every age studied, with a maximum at 4 weeks for both sexes (Fig. 3E and F). As we had previously reported age differences in PTP1B levels in normal mice of another strain, samples from non-transgenic animals were run separately to assess age differences. Maximal PTP1B abundance was found at 2 weeks of age and declined thereafter (Supplementary Figure $1 \mathrm{C}$ and D), in agreement with previous observations (Martinez et al. 2013).

\section{SOCS protein content and gene expression}

CIS, SOCS2, and SOCS3 are SOCS induced by GH in the liver; therefore, their hepatic content and gene expression were evaluated in growing GH-overexpressing mice by IB and quantitative RT-PCR respectively.

Transgenic mice had increased liver CIS expression at every age studied compared with normal siblings, both for protein and mRNA content (Fig. 4A, B, C and D). For protein abundance, highest CIS levels were observed in 4-week-old GH-overexpressing animals. In normal mice, CIS content was almost undetectable when samples were run next to those of transgenic animals; therefore, they were assessed separately. Non-transgenic 2-week-old animals exhibited higher CIS levels, while 4- and 9-weekold animals had similar abundance (Supplementary Figure $1 \mathrm{E}$ and $\mathrm{F}$ ) in accordance with previous observations of another mouse strain (Martinez et al. 2013). When assessed by age, Cis mRNA content was higher at 2 weeks and similar at 4 and 9 weeks both in normal and transgenic
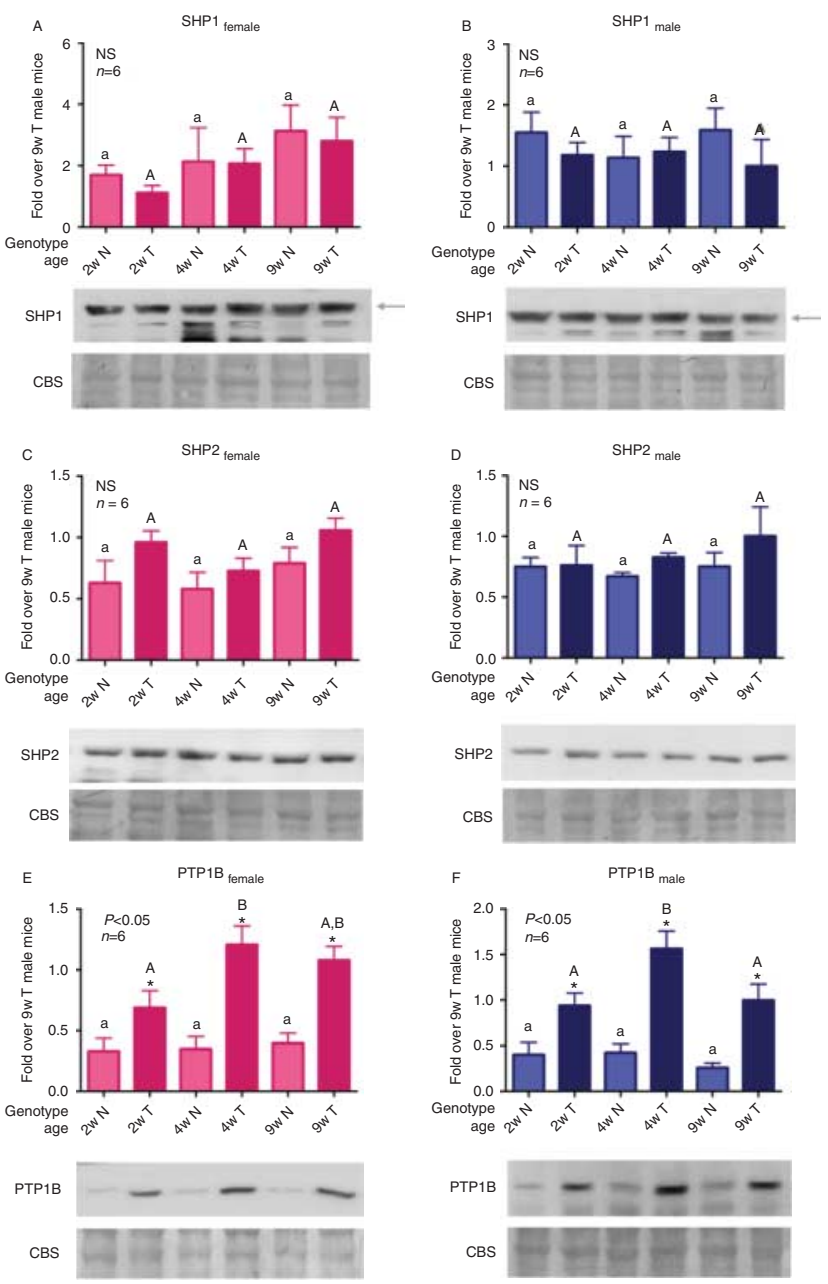

Figure 3

Phosphatase protein abundance in livers of growing $\mathrm{GH}$-overexpressing mice and normal littermates. (A) SHP1 content in female mice. (B) SHP1 content in male mice. (C) SHP2 content in female mice. (D) SHP2 content in male mice. (E) PTP1B content in female mice. (F) PTP1B content in male mice. Immunoblotting quantification was expressed as the fold increase relative to 9-week-old transgenic male mice. Data are the mean \pm s.E.M. of the indicated $n$ number of samples per group, each one representing a different animal. Different letters denote significant differences with respect to age: lower case letters correspond to normal mice and upper case letters to transgenic animals; asterisks indicate significant differences with respect to genotype. NS stands for non-significant. Arrows indicate the quantified bands. A full colour version of this figure is available at http://dx.doi.org/10.1530/JME-14-0262.

mice, closely resembling the protein profile in normal mice (shown in Supplementary Figure 1E and F). Differences were less pronounced in transgenic female animals.

SOCS3 protein content was lower in transgenic mice than in normal animals at every age studied. Normal mice presented an age-dependent pattern, with lower values at 2 weeks, which gradually increased to achieve adult values. Transgenic mice, in contrast, presented almost undetectable levels of the suppressor at every age evaluated

Published by Bioscientifica Ltd 

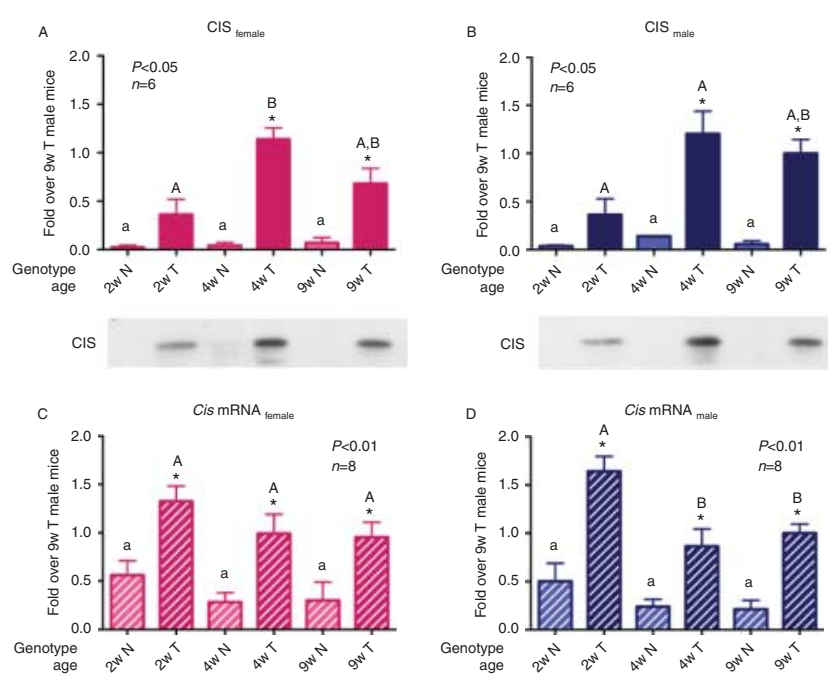

\section{Figure 4}

$\mathrm{CIS}$ expression in livers of growing $\mathrm{GH}$-overexpressing mice and normal littermates. (A) CIS protein content in female mice. (B) CIS protein content in male mice. (C) Cis mRNA expression in female mice. (D) Cis mRNA expression in male mice. To determine protein abundance, CIS required immunoprecipitation to enrich preparations prior to immunoblotting assays; mRNA was assessed by qRT-PCR. Results were expressed as the fold increase relative to 9-week-old transgenic male mice. Data are the mean \pm S.E.M. of the indicated $n$ number of samples per group, each one representing a different animal. Different letters denote significant differences with respect to age; lower case letters correspond to normal mice and upper case letters to transgenic animals. Asterisks indicate significant differences with respect to genotype. A full colour version of this figure is available at http://dx.doi.org/10.1530/JME-14-0262.

(Fig. 5A and B). Hepatic SOCS2 protein content displayed a similar pattern; normal mice exhibited a gradual increase with age, whereas transgenic animals exhibited uniform values that were lower than those of 2-week-old normal animals (Fig. 5C and D). As SOCS3 and SOCS2 are induced by GH, like CIS, their protein contents in transgenic mice would have been expected to be higher or at least the same as those in normal animals, rather than lower. To elucidate this controversy, SOCS3 and SOCS2 gene expression was assessed. Socs3 mRNA hepatic content was higher in GH-overexpressing animals than in normal siblings at every age studied, genotype statistical significance was achieved for 9-week-old animals. Moreover, Socs3 mRNA content exhibited an age-dependent increment for both genotypes (Fig. 5E and F). Socs2 mRNA expression was also higher in GH-overexpressing animals than in control siblings at every age studied. However, whereas hepatic Socs 2 mRNA content displayed a declining tendency as a function of age for normal animals, GH-transgenic mice presented a different scenario, with higher values at 2 weeks of age, compared with 4-week-old animals or the young adults (Fig. 5G and H).

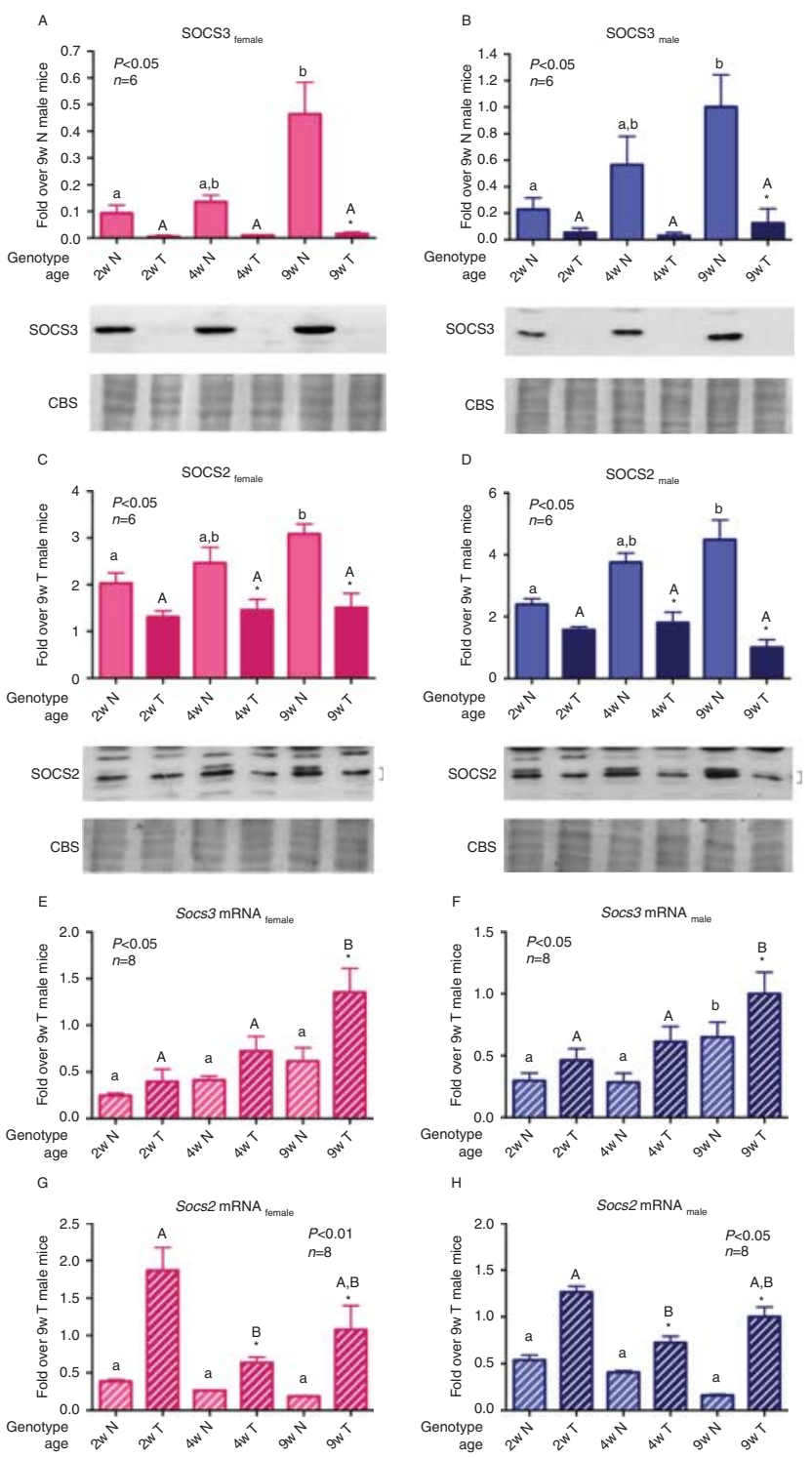

\section{Figure 5}

SOCS expression in livers of growing $\mathrm{GH}$-overexpressing mice and normal littermates. (A) SOCS3 protein content in female mice. (B) SOCS3 protein content in male mice. (C) SOCS2 protein content in female mice. (D) SOCS2 protein content in male mice. (E) Socs3 mRNA expression in female mice. (F) Socs3 mRNA expression in male mice. (G) Socs2 mRNA expression in female mice. $(H)$ Socs2 mRNA expression in male mice. To determine protein abundance, equal amounts of solubilized liver protein were analyzed by immunoblotting. Coomassie blue staining (CBS) of PVDF membranes is shown. Bands obtained were quantified by scanning densitometry. mRNA was assessed by qRT-PCR of total RNA extracts. Results were expressed as the fold increase relative to the results for 9-week-old normal ( $A$ and $B$ ) or transgenic $(C, D, E, F, G$ and $H$ ) female and male mice. Data are the mean \pm s.E.M. of the indicated $n$ number of samples per group, each one representing a different animal. Different letters denote significant differences with respect to age; lower case letters correspond to normal mice and upper case letters to transgenic animals. Asterisks indicate significant differences with respect to genotype. Square brackets indicate the quantified bands. A full colour version of this figure is available at http://dx.doi.org/10.1530/JME-14-0262.

Published by Bioscientifica Ltd. 


\section{STAT5 modulators abundance}

Hepatic STAT5 activity is also inhibited by FGF21 and BCL6. FGF21 protein content did not vary with age in normal mice of both sexes, while it was high in 2-week-old transgenic animals and declined thereafter, attaining levels similar to those for normal animals (Fig. 6A and B). BCL6 displayed a trend towards increasing levels during the
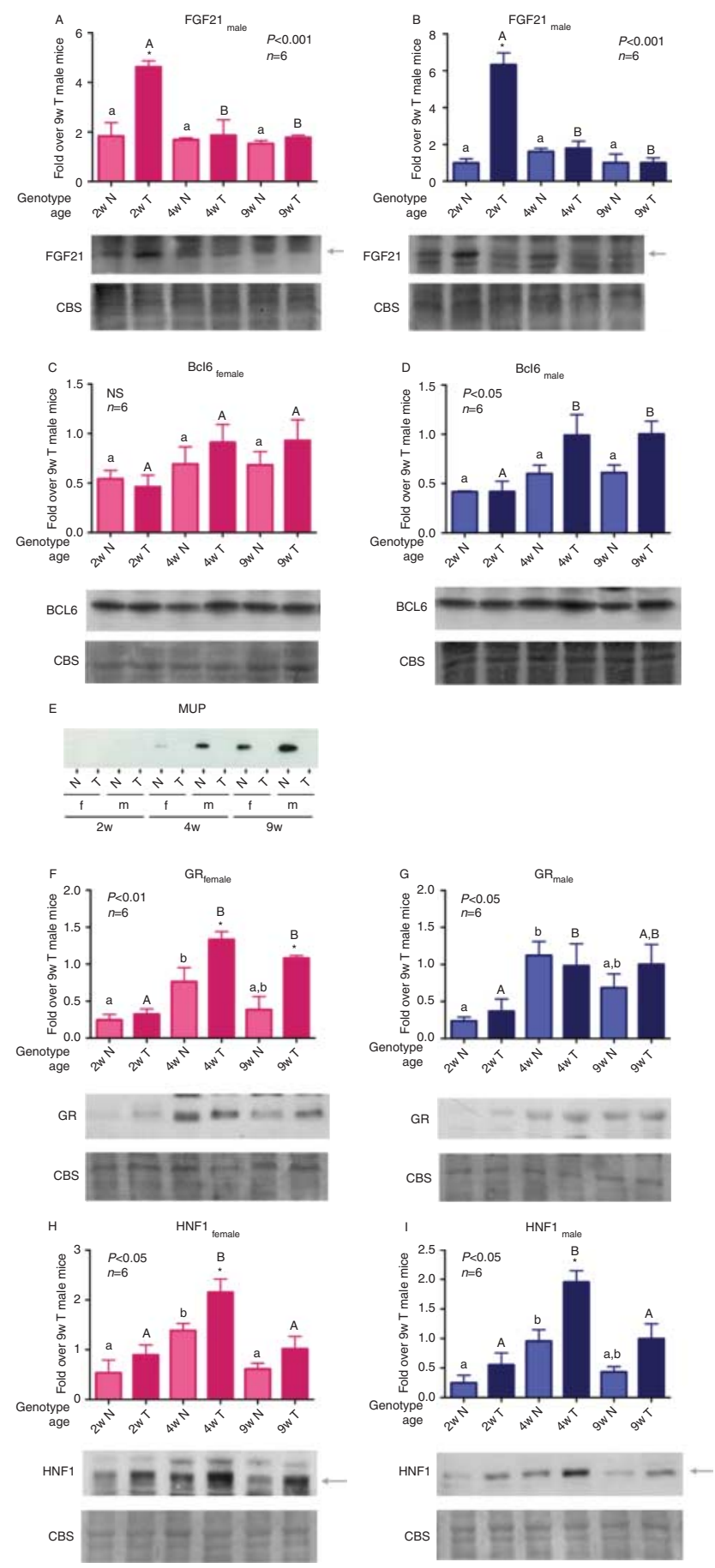

http://jme.endocrinology-journals.org DOI: 10.1530/JME-14-0262 growth period in both normal and transgenic mice, reaching statistical significance for GH-overexpressing males only. Moreover, transgenic animals exhibited higher BCL6 levels than their normal siblings at 4 and 9 weeks of age (Fig. 6C and D).

BCL6 has been reported to be suppressed by GH (Chen et al. 2009, Meyer et al. 2009). In GH-transgenic mice, the hormone is produced in extrapituitary tissues; thus, secretion in these animals is not centrally regulated, resulting in a continuous pattern of circulating GH. Therefore, the GH-secretory status of these animals was assessed by determination of an indirect marker, the major urinary proteins (MUPs). MUP expression and secretion are regulated by the intermittent secretion of $\mathrm{GH}$ and can be used as pulsatility markers of the somatotropic axis. MUPs were detected only in normal mice of 4 and 9 weeks of age, after the onset of puberty, with higher levels in males than in females, as expected (Fig. 6E). These results are consistent with the continuous GH secretory pattern of transgenic mice.

STAT5 activity is positively modulated in the liver by GR and hepatic nuclear factor 1 (HNF1). Normal and transgenic mice displayed a similar age-related GR pattern: low levels at 2 weeks, maximal values at 4 weeks, and slightly lower levels in adulthood (Fig. 6F and G). From the fourth week onward, GH-overexpressing mice exhibited higher content than non-transgenic siblings in female mice. For HNF1, the same age profile was observed (Fig. $6 \mathrm{H}$ and I). Transgenic mice had higher levels at every age, which became a significant difference at 4 weeks.

\section{Discussion}

Previous reports from our laboratory revealed the inability of adult GH-overexpressing giant mice to respond to a $\mathrm{GH}$

\section{Figure 6}

STAT5 modulators protein abundance in livers of growing GH-overexpressing mice and normal littermates. (A) FGF21 content in female mice. (B) FGF21 content in male mice. (C) BCL6 content in female mice. (D) BCL6 content in male mice. (E) Representative immunoblot for MUPs protein content. (F) GR content in female mice. (G) GR content in male mice. (H) HNF1 content in female mice. (I) HNF1 content in male mice. Immunoblotting quantification was expressed as the fold increase relative to the values for 9-week-old transgenic male mice. Data are the mean \pm S.E.M. of the indicated $n$ number of samples per group, each one representing a different animal. Different letters denote significant differences with respect to age; lower case letters correspond to normal mice and upper case letters to transgenic animals. Asterisks indicate significant differences between $\mathrm{GH}$-overexpressing animals and their corresponding non-transgenic age controls. Arrows indicate the quantified bands. A full colour version of this figure is available at http://dx. doi.org/10.1530/JME-14-0262.

Published by Bioscientifica Ltd. 
stimulus, both in different tissues and in different GH-transgenic lines. Moreover, basal STAT5 phosphorylation in those GH-overexpressing adults was not higher than that in their non-transgenic littermates, although these animals have greatly elevated circulating GH levels (Gonzalez et al. 2002, Miquet et al. 2004, Sotelo et al. 2008). Current results indicate that GH-induced STAT5 insensitivity at every age studied in GH-transgenic mice. However, there is an age-dependent variation in basal STAT5 activation, which is higher during the GH-dependent phase of growth, indicating that this pathway is involved in the accelerated growth these mice exhibit. After this initial finding, the next goal was to elucidate the contribution of different modulators of the GH-STAT5 signaling pathway in order to dissect the mechanisms that might account for differences between normal and transgenic mice involved in the regulation of this pathway during the growth period.

GHR levels are low during fetal and early postnatal periods, probably contributing to the lack of an effect of GH on somatic growth in the perinatal stage (Jiang et al. 2007). GH itself upregulates GHR expression in the liver (Maiter et al. 1988, Iida et al. 2004, Gonzalez et al. 2007), in fact, GHR has been shown to be induced by GH through STAT5 signaling in cattle (Jiang et al. 2007). In growing GH-overexpressing mice, GHR expression is slightly higher than that in normal littermates at 2 weeks of age, but it is markedly increased at the 4 weeks of age, when these animals can be distinguished from their control siblings by their increased body size, coinciding with maximal STAT5 endogenous phosphorylation. However, although adult transgenic mice exhibit higher GHR abundance than controls, they do not have greater pSTAT5 levels, indicating the existence of mechanisms that attenuate GH signaling in transgenic adults.

Negative regulation of GH-signaling may be achieved by different effectors. Fast-acting mechanisms include recruitment of protein tyrosine-phosphatases involved in the recycling of STATs proteins (Kornfeld et al. 2008); in particular, PTP1B, SHP1, and SHP2 have been related to STAT5. SHP1 and SHP2 presented no significant age- or genotype-related differences, whereas PTP1B content was elevated in transgenic mice at all ages, indicating that this phosphatase may participate in GH-insensitivity by rapidly dephosphorylating activated substrates.

Other negative modulators of the GH-STAT5 pathway are the transcriptional feedback regulators, the SOCS, which are induced as early-response genes. CIS was overexpressed in GH-transgenic animals and presented an agedependent profile, indicating that this suppressor contributes to the mitigation of GH action at every age under GH-overexpression conditions. In fact, CIS has been regarded as the only factor downregulating STAT5-mediated GH-signaling under continuous exposure to the hormone (Thangavel \& Shapiro 2007). Like GHR, CIS reached higher levels at 4 weeks of age, coinciding with the higher basal STAT5 phosphorylation found in transgenic animals. This is not unexpected, because CIS has also been shown to be induced through STAT5 (Verdier et al. 1998). Moreover, the parallel between the GH-induced age-variation in CIS and GHR is consistent with CIS-mediated internalization of the receptor to limit GH-induced signaling (Landsman \& Waxman 2005). In contrast, the hepatic protein content of the negative regulators SOCS3 and SOCS2 was lower in transgenic mice compared with normal siblings at every age studied. This behavior, although surprising, as these suppressors are induced by $\mathrm{GH}$, is in agreement with our previous observations in GH-overexpressing adult animals (Gonzalez et al. 2002, Miquet et al. 2004, Sotelo et al. 2008). SOCS2 was shown to bind to SOCS1 and SOCS3 and to target them for proteosomal degradation, therefore putting an end to the SOCS termination signal and allowing the resensitization of the JAK2/STAT5 pathway (Tannahill et al. 2005, Flores-Morales et al. 2006, Piessevaux et al. 2006, Croker et al. 2008). When Socs 3 and Socs 2 mRNA levels were analyzed, higher expression of both genes was found in transgenic animals, indicating that these suppressors are being effectively induced by the elevated GH levels. Therefore, even when Socs 3 and Socs 2 gene transcription is increased in transgenic mice, the protein content of these suppressors is decreased, indicating that they are being actively degraded, probably as a consequence of their own negative regulation. Moreover, SOCS2 has been shown to be a key regulator of GHR sensitivity, as it is part of a ubiquitin ligase complex that regulates GHR levels (Vesterlund et al. 2011).

In addition, STAT5 activity is inhibited in the liver by FGF21 and BCL6. FGF21 is a hepatic hormone involved in energy homeostasis, it is induced by fasting and may participate in liver GH-activated STAT5-signaling downregulation caused by food deprivation (Inagaki et al. 2008, Kliewer \& Mangelsdorf 2010, Kubicky et al. 2012). Moreover, FGF21 expression has also been reported to be induced by GH through STAT5 in that tissue, indicative of the existence of another negative feedback loop to restrain GH-STAT5 signaling (Yu et al. 2012). Our results from transgenic mice revealed higher levels at 2 weeks of age, which do not coincide with the maximal basal STAT5 phosphorylation found at 4 weeks. However, FGF21 has been proposed to inhibit STAT5 activation by promoting SOCS2 expression (Inagaki et al. 2008), and the elevated

Published by Bioscientifica Ltd. 
levels of FGF21 in 2-week-old transgenic mice correlate with high levels of Socs 2 mRNA found at that age. In accordance, STAT5 phosphorylation is low in 2-week-old transgenic animals, despite the high STAT5 protein content these mice display.

BCL6 is a strong transcriptional repressor of STAT5 activity, and in turn, STAT5 is a repressor of Bcl6 expression. Complete suppression of Bcl6 is achieved in the livers of female rats, related to the permanent low activation of STAT5 found in this sex, whereas male interpulse STAT5 deactivation may be permissive of BCL6 expression (Chen et al. 2009, Meyer et al. 2009, Zhang et al. 2012). In mice, this dimorphism is not as pronounced (Meyer et al. 2009). Transgenic animals exhibit continuous GH levels in both sexes; however, BCL6 levels are higher than those of nontransgenic controls. Moreover, Bcl6 mRNA levels have been reported to increase after puberty only in male rats (Meyer et al. 2009), in contrast to our observations of a moderate increase with age in both sexes and genotypes. Altogether, these results indicate that BCL6 becomes involved in GH-signaling after sexual maturation in GH-overexpressing mice, in an attempt to reduce the female-specific expression of genes promoted by STAT5 that would predominate in these animals due to the continuous GH profile.

GR acts in synergism with STAT5 in liver to induce the expression of GH-responsive genes related to body growth (Tronche et al. 2004, Engblom et al. 2007). GR protein content displayed an age-dependent pattern with a maximum at 4 weeks of age for both genotypes, indicating its active participation in the growth phenomenon. However, this pattern was not observed in another mouse strain, the Swiss-Webster (CS Martinez, VG Piazza, JG Miquet and AI Sotelo unpublished observations). HNF1 $\alpha$ is another transcription factor required for postnatal growth, which regulates GR transcription activity, indirectly mediating the action of STAT5 (Lee et al. 1998, Lin et al. 2008). In livers of growing mice, HNF1 $\alpha$ had the same agerelated profile as GR, with increased levels in transgenic mice as well. HNF1 $\alpha$ is not directly regulated by GH; however, $\mathrm{GH}$ triggers a network of transcription factors that culminates in HNF1 $\alpha$ activation, which has been reported in several species (Lahuna et al. 2000, Rastegar et al. 2000, Eleswarapu \& Jiang 2005).

The relevance of hepatic GHR/STAT5 signaling in body growth has been questioned (Kaplan \& Cohen 2007, Klover $\&$ Hennighausen 2007). Moreover, recent evidence is indicative of the involvement of this signaling pathway in lipid metabolism in this organ (Fan et al. 2009, Barclay et al. 2011, Mueller et al. 2011). However, these effects do not need to be mutually exclusive, and there is strong support for the implication of the GH/GHR/STAT5/IGF1 axis in liver in somatic growth. Results of studies of animals with hepatic deletion of STAT5, GR, or HNF1 indicate the interrelation of these three factors in the growth outcome (Tronche et al. 2004, Engblom et al. 2007, Lin et al. 2008, Mueller et al. 2012). Moreover, liver STAT5 deletion in GH-overexpressing mice abolished the giant phenotype of the latter (Friedbichler et al. 2012); JAK2 hepatic deletion is also associated with reduced size (Shi et al. 2012). Liver specific deletion of the GHR in mice yielded animals with diminished adult body weight and length (List et al. 2014). Results presented here indicate that $\mathrm{GH}$ participates in the molecular mechanisms that regulate the second phase of rapid growth before the manifestation of growth changes, i.e., before the third week of life, indicating that the intracellular machinery is set in action before growth. Our results are in agreement with those of the initial characterization of GH-transgenic models, in which hepatic IGF1 has been shown to be upregulated as early as the second week of life (Mathews et al. 1988). These authors had also observed the persistency of high IGF1 levels during adulthood in that GH-overexpression model (Mt-bGH mice) and concluded that the animals were already maximally stimulated. More recently, $I g f 1$ has been reported not to be a predictable marker of GH function in mice (Bielohuby et al. 2011), which may account for the lack of correlation we found between basal STAT5 phosphorylation levels and IGF1 induction in adult animals.

In summary, even though the principal GH signaling pathway STAT5 is desensitized in the liver of GH-overexpressing mice, it is basally active during the growth period and may be involved in the augmented growth these mice exhibit. Accompanying this higher basal STAT5 activation, there is a change in GH-signaling modulators directly or indirectly regulated by the hormone through the same pathway. Thus, GHR and the coactivators GR and HNF1, as well as negative regulators such as CIS and PTP1B, are upregulated in GH-transgenic mice, especially during the GH-dependent phase of growth. SOCS2 and SOCS3, in contrast, present lower protein levels in $\mathrm{GH}$-overexpressing mice than in non-transgenic littermates; however, their gene expression was upregulated in these animals, indicating that they are involved in active degradation to modulate GH signals. Thus, STAT5 signaling is enhanced during the growth period in the livers of GH-overexpressing mice, when transgenic mice exhibit accelerated growth, revealing a counterbalance between upregulation of positive and negative modulators that later in life seem to restrain basal STAT5 activation and to bring it close to normal levels. Moreover, the upregulation of negative

Published by Bioscientifica Ltd. 
modulators of STAT5 activation may account for the lack of sensitivity toward the GH-exogenous stimulus found for these GH-overexpressing mice at every age studied.

\section{Supplementary data}

This is linked to the online version of the paper at http://dx.doi.org/10.1530/ JME-14-0262.

\section{Declaration of interest}

The authors declare that there is no conflict of interest that could be perceived as prejudicing the impartiality of the research reported.

\section{Funding}

Support for these studies was provided by the Universidad de Buenos Aires (UBA) (B811 and 20020100100631), the Consejo Nacional de Investigaciones Científicas y Técnicas (CONICET) (PIP 427), and the Agencia Nacional de Promoción Científica y Tecnológica (ANPCYT) (PICT 38247 and PICT 0398) (Argentina) to D T and A I S and by the National Institute of Aging (grant numbers AG019899, AG031736) to A B. D T, A I S, J G M, L G and D B-V are Career Investigators of CONICET, the National Council for Scientific and Technological Research; C S M, V G P, M E D and M C R were supported by a fellowship from CONICET.

\section{Acknowledgements}

The authors thank Dr S J Frank for the anti-GHR antibody. They thank Michal Masternak, Feiya Wang, Adam Spong, Reyhan Westbrook, Cristal Hill and Yiming Fang for their laboratory assistance.

\section{References}

Adams TE, Hansen JA, Starr R, Nicola NA, Hilton DJ \& Billestrup N 1998 Growth hormone preferentially induces the rapid, transient expression of SOCS-3, a novel inhibitor of cytokine receptor signaling. Journal of Biological Chemistry 273 1285-1287. (doi:10.1074/jbc.273.3.1285)

Barclay JL, Kerr LM, Arthur L, Rowland JE, Nelson CN, Ishikawa M, d'Aniello EM, White M, Noakes PG \& Waters MJ 2010 In vivo targeting of the growth hormone receptor (GHR) Box1 sequence demonstrates that the GHR does not signal exclusively through JAK2. Molecular Endocrinology 24 204-217. (doi:10.1210/me.2009-0233)

Barclay JL, Nelson CN, Ishikawa M, Murray LA, Kerr LM, McPhee TR, Powell EE \& Waters MJ 2011 GH-dependent STAT5 signaling plays an important role in hepatic lipid metabolism. Endocrinology 152 181-192. (doi:10.1210/en.2010-0537)

Bielohuby M, Schaab M, Kummann M, Sawitzky M, Gebhardt R, Binder G, Frystyk J, Bjerre M, Hoeflich A, Kratzsch J et al. 2011 Serum IGF-I is not a reliable pharmacodynamic marker of exogenous growth hormone activity in mice. Endocrinology 152 4764-4776. (doi:10.1210/en.2011-1432)

Brooks AJ \& Waters MJ 2010 The growth hormone receptor: mechanism of activation and clinical implications. Nature Reviews. Endocrinology 6 515-525. (doi:10.1038/nrendo.2010.123)

Chen Y, Lin G, Huo JS, Barney D, Wang Z, Livshiz T, States DJ, Qin ZS \& Schwartz J 2009 Computational and functional analysis of growth hormone $(\mathrm{GH})$-regulated genes identifies the transcriptional repressor B-cell lymphoma 6 (Bc16) as a participant in GH-regulated transcription. Endocrinology 150 3645-3654. (doi:10.1210/en.2009-0212)
Croker BA, Kiu H \& Nicholson SE 2008 SOCS regulation of the JAK/STAT signalling pathway. Seminars in Cell \& Developmental Biology 19 414-422. (doi:10.1016/j.semcdb.2008.07.010)

Eleswarapu S \& Jiang H 2005 Growth hormone regulates the expression of hepatocyte nuclear factor-3 gamma and other liver-enriched transcription factors in the bovine liver. Journal of Endocrinology $\mathbf{1 8 4}$ 95-105. (doi:10.1677/joe.1.05821)

Engblom D, Kornfeld JW, Schwake L, Tronche F, Reimann A, Beug H, Hennighausen L, Moriggl R \& Schutz G 2007 Direct glucocorticoid receptor-Stat 5 interaction in hepatocytes controls body size and maturation-related gene expression. Genes and Development 21 1157-1162. (doi:10.1101/gad.426007)

Fan Y, Menon RK, Cohen P, Hwang D, Clemens T, DiGirolamo DJ, Kopchick JJ, Le Roith D, Trucco M \& Sperling MA 2009 Liver-specific deletion of the growth hormone receptor reveals essential role of growth hormone signaling in hepatic lipid metabolism. Journal of Biological Chemistry 284 19937-19944. (doi:10.1074/jbc.M109.014308)

Flores-Morales A, Greenhalgh CJ, Norstedt G \& Rico-Bautista E 2006 Negative regulation of growth hormone receptor signaling. Molecular Endocrinology 20 241-253. (doi:10.1210/me.2005-0170)

Friedbichler K, Themanns M, Mueller KM, Schlederer M, Kornfeld JW, Terracciano LM, Kozlov AV, Haindl S, Kenner L, Kolbe T et al. 2012 Growth-hormone-induced signal transducer and activator of transcription 5 signaling causes gigantism, inflammation, and premature death but protects mice from aggressive liver cancer. Hepatology 55 941-952. (doi:10.1002/hep.24765)

Gonzalez L, Miquet JG, Sotelo AI, Bartke A \& Turyn D 2002 Cytokineinducible $\mathrm{SH} 2$ protein up-regulation is associated with desensitization of GH signaling in GHRH-transgenic mice. Endocrinology 143 386-394. (doi:10.1210/endo.143.2.8616)

Gonzalez L, Curto LM, Miquet JG, Bartke A, Turyn D \& Sotelo AI 2007 Differential regulation of membrane associated-growth hormone binding protein (MA-GHBP) and growth hormone receptor (GHR) expression by growth hormone (GH) in mouse liver. Growth Hormone \& IGF Research 17 104-112. (doi:10.1016/j.ghir.2006.12.002)

Hyatt MA, Walker DA, Stephenson T \& Symonds ME 2004 Ontogeny and nutritional manipulation of the hepatic prolactin-growth hormoneinsulin-like growth factor axis in the ovine fetus and in neonate and juvenile sheep. Proceedings of the Nutrition Society 63 127-135. (doi:10.1079/PNS2003324)

Iida K, Del Rincon JP, Kim DS, Itoh E, Nass R, Coschigano KT, Kopchick JJ \& Thorner MO 2004 Tissue-specific regulation of growth hormone (GH) receptor and insulin-like growth factor-I gene expression in the pituitary and liver of GH-deficient (lit/lit) mice and transgenic mice that overexpress bovine GH (bGH) or a bGH antagonist. Endocrinology 145 1564-1570. (doi:10.1210/en.2003-1486)

Inagaki T, Lin VY, Goetz R, Mohammadi M, Mangelsdorf DJ \& Kliewer SA 2008 Inhibition of growth hormone signaling by the fasting-induced hormone FGF21. Cell Metabolism 8 77-83. (doi:10.1016/j.cmet.2008. 05.006)

Jiang H, Wang Y, Wu M, Gu Z, Frank SJ \& Torres-Diaz R 2007 Growth hormone stimulates hepatic expression of bovine growth hormone receptor messenger ribonucleic acid through signal transducer and activator of transcription 5 activation of a major growth hormone receptor gene promoter. Endocrinology 148 3307-3315. (doi:10.1210/ en.2006-1738)

Kaplan SA \& Cohen P 2007 The somatomedin hypothesis 2007: 50 years later. Journal of Clinical Endocrinology and Metabolism 92 4529-4535. (doi:10.1210/jc.2007-0526)

Kile BT, Schulman BA, Alexander WS, Nicola NA, Martin HM \& Hilton DJ 2002 The SOCS box: a tale of destruction and degradation. Trends in Biochemical Sciences 27 235-241. (doi:10.1016/S0968-0004(02)02085-6)

Kliewer SA \& Mangelsdorf DJ 2010 Fibroblast growth factor 21: from pharmacology to physiology. American Journal of Clinical Nutrition 91 254S-257S. (doi:10.3945/ajcn.2009.28449B) 
Klover P \& Hennighausen L 2007 Postnatal body growth is dependent on the transcription factors signal transducers and activators of transcription $5 \mathrm{a} / \mathrm{b}$ in muscle: a role for autocrine/paracrine insulin-like growth factor I. Endocrinology 148 1489-1497. (doi:10.1210/en.2006-1431)

Kornfeld JW, Grebien F, Kerenyi MA, Friedbichler K, Kovacic B, Zankl B, Hoelbl A, Nivarti H, Beug H, Sexl V et al. 2008 The different functions of Stat5 and chromatin alteration through Stat5 proteins. Frontiers in Bioscience 13 6237-6254. (doi:10.2741/3151)

Kubicky RA, Wu S, Kharitonenkov A \& De Luca F 2012 Role of fibroblast growth factor 21 (FGF21) in undernutrition-related attenuation of growth in mice. Endocrinology 153 2287-2295. (doi:10.1210/ en.2011-1909)

Lahuna O, Rastegar M, Maiter D, Thissen JP, Lemaigre FP \& Rousseau GG 2000 Involvement of STAT5 (signal transducer and activator of transcription 5) and HNF-4 (hepatocyte nuclear factor 4) in the transcriptional control of the hnf6 gene by growth hormone. Molecular Endocrinology 14 285-294. (doi:10.1210/mend.14.2.0423)

Landsman T \& Waxman DJ 2005 Role of the cytokine-induced SH2 domain-containing protein CIS in growth hormone receptor internalization. Journal of Biological Chemistry 280 37471-37480. (doi:10.1074/ jbc.M504125200)

Lanning NJ \& Carter-Su C 2006 Recent advances in growth hormone signaling. Reviews in Endocrine \& Metabolic Disorders 7 225-235. (doi:10.1007/s11154-007-9025-5)

Lee YH, Sauer B \& Gonzalez FJ 1998 Laron dwarfism and non-insulindependent diabetes mellitus in the Hnf-1 $\alpha$ knockout mouse. Molecular and Cellular Biology 18 3059-3068.

Lin WY, Hu YJ \& Lee YH 2008 Hepatocyte nuclear factor-1 $\alpha$ regulates glucocorticoid receptor expression to control postnatal body growth. American Journal of Physiology. Gastrointestinal and Liver Physiology 295 G542-G551. (doi:10.1152/ajpgi.00081.2008)

Linossi EM \& Nicholson SE 2012 The SOCS box-adapting proteins for ubiquitination and proteasomal degradation. IUBMB Life 64 316-323. (doi:10.1002/iub.1011)

List EO, Berryman DE, Funk K, Jara A, Kelder B, Wang F, Stout MB, Zhi X, Sun L, White TA et al. 2014 Liver-specific GH receptor gene disrupted (LiGHRKO) mice have decreased endocrine IGF-1, increased local IGF-1 as well as altered body size, body composition and adipokine profiles. Endocrinology 155 1793-1805. (doi:10.1210/en.2013-2086)

Liu JL \& LeRoith D 1999 Insulin-like growth factor I is essential for postnatal growth in response to growth hormone. Endocrinology 140 5178-5184. (doi:10.1210/endo.140.11.7151)

Lupu F, Terwilliger JD, Lee K, Segre GV \& Efstratiadis A 2001 Roles of growth hormone and insulin-like growth factor 1 in mouse postnatal growth. Developmental Biology 229 141-162. (doi:10.1006/dbio.2000.9975)

Maes M, De Hertogh R, Watrin-Granger P \& Ketelslegers JM 1983 Ontogeny of liver somatotropic and lactogenic binding sites in male and female rats. Endocrinology 113 1325-1332. (doi:10.1210/endo-113-4-1325)

Maiter D, Underwood LE, Maes M, Davenport ML \& Ketelslegers JM 1988 Different effects of intermittent and continuous growth hormone $(\mathrm{GH})$ administration on serum somatomedin-C/insulin-like growth factor I and liver GH receptors in hypophysectomized rats. Endocrinology 123 1053-1059. (doi:10.1210/endo-123-2-1053)

Martinez CS, Piazza VG, Ratner LD, Matos MN, Gonzalez L, Rulli SB, Miquet JG \& Sotelo AI 2013 Growth hormone STAT5-mediated signaling and its modulation in mice liver during the growth period. Growth Hormone \& IGF Research 23 19-28. (doi:10.1016/j.ghir.2012.11.002)

Mathews LS, Hammer RE, Brinster RL \& Palmiter RD 1988 Expression of insulin-like growth factor I in transgenic mice with elevated levels of growth hormone is correlated with growth. Endocrinology 123 433-437. (doi:10.1210/endo-123-1-433)

Mathews LS, Enberg B \& Norstedt G 1989 Regulation of rat growth hormone receptor gene expression. Journal of Biological Chemistry 264 9905-9910.

McGrane MM, Yun JS, Moorman AF, Lamers WH, Hendrick GK, Arafah BM, Park EA, Wagner TE \& Hanson RW 1990 Metabolic effects of developmental, tissue-, and cell-specific expression of a chimeric phosphoenolpyruvate carboxykinase (GTP)/bovine growth hormone gene in transgenic mice. Journal of Biological Chemistry 265 22371-22379.

Meyer RD, Laz EV, Su T \& Waxman DJ 2009 Male-specific hepatic Bcl6: growth hormone-induced block of transcription elongation in females and binding to target genes inversely coordinated with STAT5. Molecular Endocrinology 23 1914-1926. (doi:10.1210/me.2009-0242)

Miquet JG, Sotelo AI, Bartke A \& Turyn D 2004 Suppression of growth hormone $(\mathrm{GH})$ Janus tyrosine kinase 2/signal transducer and activator of transcription 5 signaling pathway in transgenic mice overexpressing bovine GH. Endocrinology 145 2824-2832. (doi:10.1210/en.2003-1498)

Miquet JG, Freund T, Martinez CS, Gonzalez L, Diaz ME, Micucci GP, Zotta E, Boparai RK, Bartke A, Turyn D et al. 2013 Hepatocellular alterations and dysregulation of oncogenic pathways in the liver of transgenic mice overexpressing growth hormone. Cell Cycle 12 1042-1057. (doi:10.4161/cc.24026)

Mueller KM, Kornfeld JW, Friedbichler K, Blaas L, Egger G, Esterbauer H, Hasselblatt P, Schlederer M, Haindl S, Wagner KU et al. 2011 Impairment of hepatic growth hormone and glucocorticoid receptor signaling causes steatosis and hepatocellular carcinoma in mice. Hepatology 54 1398-1409. (doi:10.1002/hep.24509)

Mueller KM, Themanns M, Friedbichler K, Kornfeld JW, Esterbauer H, Tuckermann JP \& Moriggl R 2012 Hepatic growth hormone and glucocorticoid receptor signaling in body growth, steatosis and metabolic liver cancer development. Molecular and Cellular Endocrinology 361 1-11. (doi:10.1016/j.mce.2012.03.026)

Piessevaux J, Lavens D, Montoye T, Wauman J, Catteeuw D, Vandekerckhove J, Belsham D, Peelman F \& Tavernier J 2006 Functional crossmodulation between SOCS proteins can stimulate cytokine signaling. Journal of Biological Chemistry 281 32953-32966. (doi:10.1074/ jbc.M600776200)

Pilecka I, Patrignani C, Pescini R, Curchod ML, Perrin D, Xue Y, YasenchakJ, Clark A, Magnone MC, Zaratin P et al. 2007 Protein-tyrosine phosphatase $\mathrm{H} 1$ controls growth hormone receptor signaling and systemic growth. Journal of Biological Chemistry 282 35405-35415. (doi:10.1074/ jbc.M705814200)

Ramirez MC, Luque GM, Ornstein AM \& Becu-Villalobos D 2010 Differential neonatal testosterone imprinting of GH-dependent liver proteins and genes in female mice. Journal of Endocrinology $\mathbf{2 0 7}$ 301-308. (doi:10.1677/JOE-10-0276)

Rastegar M, Lemaigre FP \& Rousseau GG 2000 Control of gene expression by growth hormone in liver: key role of a network of transcription factors. Molecular and Cellular Endocrinology 164 1-4. (doi:10.1016/ S0303-7207(00)00263-X)

Rotwein P 2012 Mapping the growth hormone-Stat5b-IGF-I transcriptional circuit. Trends in Endocrinology and Metabolism 23 186-193. (doi:10.1016/j.tem.2012.01.001)

Sedek M, van der Velden LM \& Strous GJ 2014 Multimeric growth hormone receptor complexes serve as signaling platforms. Journal of Biological Chemistry 289 65-73. (doi:10.1074/jbc.M113.523373)

Shi SY, Martin RG, Duncan RE, Choi D, Lu SY, Schroer SA, Cai EP, Luk CT, Hopperton KE, Domenichiello AF et al. 2012 Hepatocyte-specific deletion of Janus kinase 2 (JAK2) protects against diet-induced steatohepatitis and glucose intolerance. Journal of Biological Chemistry 287 10277-10288. (doi:10.1074/jbc.M111.317453)

Sotelo AI, Miquet JG, Gonzalez L, Bartke A \& Turyn D 2008 Vitamin D3 cannot revert desensitization of growth hormone (GH)-induced STAT5signaling in GH-overexpressing mice non-calcemic tissues. Growth Hormone \& IGF Research 18 148-156. (doi:10.1016/j.ghir.2007.08.001)

Tang Z, Yu R, Lu Y, Parlow AF \& Liu JL 2005 Age-dependent onset of liverspecific IGF-I gene deficiency and its persistence in old age: implications for postnatal growth and insulin resistance in LID mice. American Journal of Physiology. Endocrinology and Metabolism 289 E288-E295. (doi:10.1152/ajpendo.00494.2004)

Tannahill GM, Elliott J, Barry AC, Hibbert L, Cacalano NA \& Johnston JA 2005 SOCS2 can enhance interleukin-2 (IL-2) and IL-3 signaling by

Published by Bioscientifica Ltd. 
accelerating SOCS3 degradation. Molecular and Cellular Biology 25 9115-9126. (doi:10.1128/MCB.25.20.9115-9126.2005)

Thangavel C \& Shapiro BH 2007 A molecular basis for the sexually dimorphic response to growth hormone. Endocrinology 148 2894-2903. (doi:10.1210/en.2006-1333)

Tollet-Egnell P, Flores-Morales A, Stavreus-Evers A, Sahlin L \& Norstedt G 1999 Growth hormone regulation of SOCS-2, SOCS-3, and CIS messenger ribonucleic acid expression in the rat. Endocrinology 140 3693-3704. (doi:10.1210/endo.140.8.6878)

Torre C, Benhamouche S, Mitchell C, Godard C, Veber P, Letourneur F, Cagnard N, Jacques S, Finzi L, Perret C et al. 2011 The transforming growth factor- $\alpha$ and cyclin D1 genes are direct targets of $\beta$-catenin signaling in hepatocyte proliferation. Journal of Hepatology 55 86-95. (doi:10.1016/j.jhep.2010.10.021)

Tronche F, Opherk C, Moriggl R, Kellendonk C, Reimann A, Schwake L, Reichardt HM, Stangl K, Gau D, Hoeflich A et al. 2004 Glucocorticoid receptor function in hepatocytes is essential to promote postnatal body growth. Genes and Development 18 492-497. (doi:10.1101/gad. 284704)

Verdier F, Rabionet R, Gouilleux F, Beisenherz-Huss C, Varlet P, Muller O, Mayeux P, Lacombe C, Gisselbrecht S \& Chretien S 1998 A sequence of the CIS gene promoter interacts preferentially with two associated STAT5A dimers: a distinct biochemical difference between STAT5A and STAT5B. Molecular and Cellular Biology 18 5852-5860.

http://jme.endocrinology-journals.org DOI: $10.1530 / \mathrm{JME}-14-0262$ (c) 2015 Society for Endocrinology Printed in Great Britain
Vesterlund M, Zadjali F, Persson T, Nielsen ML, Kessler BM, Norstedt G \& Flores-Morales A 2011 The SOCS2 ubiquitin ligase complex regulates growth hormone receptor levels. PLOS ONE 6 e25358. (doi:10.1371/ journal.pone.0025358)

Welinder C \& Ekblad L 2011 Coomassie staining as loading control in western blot analysis. Journal of Proteome Research 10 1416-1419. (doi:10.1021/pr1011476)

Woelfle J, Billiard J \& Rotwein P 2003 Acute control of insulin-like growth factor-I gene transcription by growth hormone through Stat5b. Journal of Biological Chemistry 278 22696-22702. (doi:10.1074/jbc. M301362200)

Yu J, Zhao L, Wang A, Eleswarapu S, Ge X, Chen D \& Jiang H 2012 Growth hormone stimulates transcription of the fibroblast growth factor 21 gene in the liver through the signal transducer and activator of transcription 5. Endocrinology 153 750-758. (doi:10.1210/ en.2011-1591)

Zhang Y, Guan R, Jiang J, Kopchick JJ, Black RA, Baumann G \& Frank SJ 2001 Growth hormone (GH)-induced dimerization inhibits phorbol ester-stimulated GH receptor proteolysis. Journal of Biological Chemistry 276 24565-24573. (doi:10.1074/jbc.M101281200)

Zhang Y, Laz EV \& Waxman DJ 2012 Dynamic, sex-differential STAT5 and BCL6 binding to sex-biased, growth hormone-regulated genes in adult mouse liver. Molecular and Cellular Biology 32 880-896. (doi:10.1128/ MCB.06312-11)

Received in final form 16 February 2015

Accepted 16 February 2015

Accepted Preprint published online 17 February 2015 